\title{
$\underline{\text { Aristotelian influence in the formation of medical theory }}$
}

\section{Mythologic cradle of Greek medical thought}

Early Greek medicine contained both natural and supernatural elements. Pharmaka, a broad term for drugs, referred to applications for magic, for poison, and for curing. The gods had a large role. The Iliad opened with an epidemic sent by Apollo, and medical solutions were often a search to discover what offended a particular god. By the time of Hesiod ( 700 B.C.), Asclepian healing ceremonies consisted of a normalized set of rituals involving abstinence from food and wine, a sacrifice or gift to the god, and a nocturnal "incubational" period. ${ }^{1}$

Aristotle stood at the portal between mythical and modern horizons of thought, and was a prime motivating agent in propelling medicine, not just philosophy, through that portal. As a natural philosopher, Aristotle's influence on medicine is two-pronged - first in terms of immediate causation - his influence on his own students and their intellectual descendents - and secondly in terms of indirect causation - his influence on medical debates raging today.

\section{The shift}

The Sicilian philosopher (and some speculate physician) Empedocles, whose life straddled the sixth and fifth centuries B.C., is credited with the notion that everything 
existing is composed of four elements - earth, air, fire, and water. ${ }^{2}$ Alcmaeon of Croton ( 470 B.C.) held to a similar natural scheme, claiming an equality of powers is responsible for health - moist and dry; cold and hot; bitter and sweet.

An interesting schism over this model developed with which Aristotle was to contend. Following Empedocles' lead, Plato ascribed to a four-element theory, having placed emphasis on universal principles, including the Forms. Alcmaeon, however, believed that investigation and even dissection, not just philosophy, was necessary to understand the body $(M I, 192){ }^{3}$ Aristotle was to wed Plato's and Alcmaeon's two strains of thought.

\section{Aristotle's influence on Greek medical practice and thought}

Aristotle was born 384 B.C. in Stagira, Thrace. His father Nicomachus was a member of the guild of the Asclepiadae, and his mother Phaestis was a member of the Asclepiad family. His father was court physician to the King of Macedon, the grandfather of Alexander the Great. Indeed, it is recorded that Aristotle served for three years as tutor to Alexander. ${ }^{4}$ According to Claudius Galen, the Asclepiad families trained their sons from childhood in anatomy on top of the basic foundation of reading and writing, a course of study that Aristotle may himself have experienced. ${ }^{5}$

Nonetheless, Aristotle broke away from his father's profession, and entered Plato's Academy at age eighteen. Like Plato, Aristotle was firmly committed to the belief that the first principles of medicine should derive from general philosophical principles. The principles Aristotle adopted included the four-element theory of earth, air, fire, and water. 
(He also subscribed to a fifth, non-terrestrial element, the "quintessence" or "ether," which he believed existed in the heavens.) However, Aristotle's beliefs additionally incorporated the criterion of "sensibility" - to him the four-element theory had to meet standards of theory and observation.

Plato contended that regularities in the patterns of nature are explainable by geometrical relations between the surfaces of bodies that symbolically represent the four elements. Aristotle felt that it is impossible for corporeal bodies to be made out of planes. An axiom of scientific explanation had been violated, he contended: "Perceptible things require perceptible principles, eternal things eternal principles, corruptible things corruptible principles" (De Caelo ("On The Heavens") 306a9-12). ${ }^{6}$ For Aristotle, the properties of matter that counted were hot and cold, dry and moist, heavy and light, hard and soft, viscous and brittle, rough and smooth, coarse and fine $(G R, 155)$. While Aristotle subscribed to a principled reality, these principles allegedly derived more from the perception of the world than from the mind. In that sense, his thought was in harmony with Alcmaeon's.

Aristotle moved these ideas in two scientific directions. First, he tried to account for change in the elements. Aristotle realized that matter's ability to go "crunch" was in need of explanation. According to him, change between the elements comes about by transformation of a contrary into its opposite - water turns into air when heat overcomes cold; air turns into fire when the moist is overpowered by the dry. These simple ideas bear an uncanny resemblance to modern thermodynamic and convection principles. They 
may also have had an influence on Western contemporary philosophy. Martin Heidegger, citing Henri Bergson's thesis “Quid Aristoteles de loco senserit” (Aristotle’s conception of place), claimed that Bergson's view of time was in essence determined by Greek thought.

The second scientific direction was a deepening of the fourfold theory of the elements with physiologic observation. The body fluids or humours were composed of varying proportions of blood (warm and moist); phlegm (cold and moist); yellow bile (warm and dry); and black bile (cold and dry) $(M I, 195) .{ }^{2}$ Disequilibrium in their balance caused disease, described in three major phases of progression by Hippocrates $(M I, 210)$. Aristotle elaborated on the function of the elements with respect to the body. Air is taken into the body to cool the "innate heat" or pneuma within. Moistness is associated with the watery composition of the tissues. He describes the semen as "wet and waterlike" (GR, 159). Beyond the substance of the body, the form has "homogeneous parts" (flesh, bone, and blood) and "heterogeneous parts" (e.g., the face, hand, and foot) $(C W, 996-7)$. Together, the material and formal levels represented the "three degrees of composition" of the human body $(C W, 1005)$. This nuanced system carried Aristotle beyond the purely philosophical domain and into the realm of medical science.

\section{Aristotle's empirical side}

It is little surprise that Aristotle's approach towards the elemental principles would learn towards the natural. Diogenes Laërtius cites two separate works by Aristotle on anatomy, and two treatises by him on medicine. Aristotle in some twenty instances 
straightforwardly refers to his Anatomai or "Dissections." This lost work, variously described by authors as existing in seven to eight volumes, was apparently an illustrated handbook with zoological commentary $(G R, 149){ }^{7}$ Aristotle's writings indicate that he dissected many animals (a practice he may have inherited from Alcmaeon) and achieved considerable skill as a comparative anatomist. He is considered by some to have been the first individual to have used dissection extensively; by others, to be the first natural historian.

Aristotle's empirical investigations moved in the direction of both the human and natural worlds. Exploration of natural history was done on the isle of Lesbos, where Aristotle wrote three volumes: History of Animals, Generation of Animals, and Parts of Animals. In these works he described embryological development in fish and sharks, ruminants' four-chambered fore-stomachs, and the distinctive sutures of the human skull. Aristotle's progressive descriptions of the heart went considerably beyond the Hippocratic writings (Hippocratic physicians did not dissect human beings), and later provoked a response from Galen about Aristotle's method of dissecting as he went about testing the philosopher's ideas.

In a very unique way, Aristotle was able to respect both principled philosophy and observational natural philosophy. Both perspectives on nature led to a personal exploration of the causes of things, and his classic description in Physics, Book II of the various causes: material (natural "substance" and "substrata"); formal (the "shape and 
form of things"); efficient (the "proximate source of change or rest"); and final (the "end or purpose of a thing"'). ${ }^{8}$

\section{Direct influence on medicine and biology}

Aristotle's tenets were transmitted by way of training students in the Lyceum and his significant body of writings. Chief among the medical advocates within the Lyceum was Diocles. Like Aristotle, he ascribed to the four-element theory and believed that the purpose of respiration was to cool the innate heat (which he contended took place through the pores of the skin as well as the nose and mouth). He is likely to have played an influential role in the development of anatomy and physiology within the school. Aristotle's successor at the Lyceum, Theophrastus, maintained the biologic tradition by writing a series of books on botany, the History of Plants and Causes of Plants, which continued as the most significant contributions to the field even in the Middle Ages (GS, 51-2). Terms coined by Theophrastus, such as carpos (fruit) and pericarpion (seed vessel), are still being used today.

Claudius Galen, considered to be the most important contributor to medicine in the several centuries occupying and following the Roman period, was measurably influenced by Aristotle's work. While Galen produced many commentaries on the Hippocratic treatises, his philosophical ideas originate mainly from Aristotle, with some input from Plato and the Stoics. ${ }^{2}$ Aristotle's principle of efficient causes is well exemplified in Galen's system of thought. Galen was especially interested in the causation of diseases and the influence of the environment on people's health. Like Aristotle, Galen depended 
on dissection for his discoveries. He agreed with Aristotle's idea of a functional form behind natural bodies such as organs, as well as his views of the four humours, having extended them into psychological types - the phlegmatic, sanguine, choleric, and melancholic. He valued both reason and observation, but felt logic should be carefully used to confirm hypotheses.

Aristotle and Galen greatly influenced the orbit of philosopher-physicians during the $10^{\text {th }}$ and $11^{\text {th }}$ centuries $(M I, 313)$. Persian born physician Avicenna (Arabic: Ibn Sina, $980-$ $1037 \mathrm{AD}$ ) incorporated Aristotelian logic and Galen's teachings into medical diagnosis and treatment. It is said that as a teenager, he read Aristotle's Metaphysics forty times before comprehending it through an illuminating commentary by al-Farabi. Like Galen, Avicenna held to Aristotle's four humour types, which he associated with signs, symptoms, and treatments. Avicenna's The Canon of Medicine began to move humour theory closer to modern medicine, and served as the standard medical text in Europe through the $17^{\text {th }}$ century $(M I, 310)$. In The Book of Healing Avicenna recommended two epistemologic methods: Aristotle's method of induction, and the method of experimentation.

Lying at the crossroads between classic and Medieval medical thought and the modern outlook was a pupil of Avicenna's, Averroes (Arabic: Ibn Rushd, 1126 - 1198 AD), also known as "The Commentator" (MI, 313). Living in Cordoba, Spain (then Al-Andalus), Averroes was commissioned by the Sultan to broadly examine Aristotle's writings, which he compiled into three diverse commentaries. Like Aristotle, Averroes believed in and 
wrote about the importance of dissection, though for him it was a means to strengthen faith.

Aristotle's influence on medicine during the Scientific Revolution permeated the work of English physician William Harvey (1578 - 1657), a self-avowed devotee of Aristotle since his medical training in Padua. ${ }^{9}$ It is thought that his hunch or hypothesis on the circularity of the bloodstream was based on the Aristotelian principle of circular motion $(N L, 4,15)$. Harvey in his De Motu Cordis even quotes Aristotle's depiction of the water cycle. Despite the use of prior principles concerning circularity and purity of blood $(N L$, $14,17 ; A P, 270)$, Harvey admonished his readers to weigh all that he was saying in the light of experience, a conviction grounded in Aristotle.

Aristotle's active observational approach clearly passed to his followers and their intellectual progeny. To this day the elucidation of causal mechanisms is of utmost importance in medical practice and health research.

\section{Indirect influence on medicine and biology}

A more indirect influence on medical theory and practice might be traced to Aristotle's notion of a final cause. Aristotle explains, "Then there is what is a cause insofar as it is an end; this is the purpose of a thing; in this sense health, for instance, is the cause of a man's going for a walk" (Physica II 194b33-35). ${ }^{8}$ Closely associated with the notion of purpose is that of chance, for random chance would seem to indicate that the behavior of a body or bodies are not governed by some purpose. Aristotle questions the role of 
chance in multiple biological examples, including the formation of teeth, "sharp and suitable for cutting things up, and ... molars [that] are flat and useful for grinding the food" (Physica II 198b24-29).

Encompassing the idea of having an end is teleology, directedness towards a definite end. William Harvey, in his examination of the role of the valves in the veinous circulation and the return of blood to the heart, was greatly impacted by Aristotle's notion of a final cause. It should be noted, however, that Aristotle's view of final causes has struck different contemporary philosophers variously. Bertrand Russell, who devoted five chapters to Aristotle in A History of Western Philosophy, questioned the notion of necessity through an argument emphasizing intervening variables $(H W, 205)$.

Whitehead mentions Aristotle's teleologic views throughout Process and Reality. In particular, he recalls Aristotle's ultimate "primary substance," the composite of all separate subjects. ${ }^{10}$ For Whitehead, there are series of successive "coming together"'s in which each subject eventually becomes organically part of a larger superject. According to Whitehead, concrescence, which perhaps in Aristotle's thought would equate with the orderly embryogenesis of a living organism or its tendency to health, is part of a natural process built into the universe.

Contemporary physicist Carl Friedrich von Weizsäcker thinks of the biologic organism not as a subject merging with a superject, but as a cybernetic control system in equilibrium with its environment (which sounds very much like ancient Greek views of harmony and balance). ${ }^{11}$ He also refers to Nietzsche's formulation that "Truth is the apt 
rendition of a state of affairs by means of a statement." In so doing he alludes to Aristotle, who claimed that speech (logos) is true if it links what is connected in things (pragmata) and separates what is distinct in them. The eidos of the individual - his or her soul - in interacting with others, either recognizes their essential "Form" and is ready to communicate, or does not and maintains insularity. If no recognition exists, and the soul is a young songbird in need of food from its mother, then it may go hungry. Health, then, is right adaptation to the circumstances.

For medical philosopher Alfred Tauber, the self may not possess a stable norm of adapative behavior as von Weizsäcker might wish. The eidos is flexible. Contends Tauber, "The self defines itself as it strives toward some undeclared and nebulous ideal."12 Tauber also refers to the overcoming of values and "will to power" about which Nietzsche wrote. The main process for these contemporary thinkers, with Aristotle and Nietzsche as the suppliers of definition, is the type of advancement the individual makes towards health.

Russian physician Konstantin Khroutski has introduced a personalist philosophy (or more accurately, cosmology) that avoids the Whiteheadian dilemma of invoking an Aristotelian "first cause" in the health-related evolution of individuals. ${ }^{13}$ Khroutski proposes that each individual has a "basic cosmist functionality" (BCF) which applies to their healthy trajectory in life. The BCF might be viewed in terms of an Aristotelian telos, or in a more contemporary sense as a biotype. 
Khroutski writes about medicine as a whole, suggesting it is moving into a new, more "personalistic" era. As medicine advances in personalized directions, it is useful to heed Aristotle's advise (Nichomachean Ethics I) that true happiness cannot be achieved in less than a complete lifetime. ${ }^{14}$ This caution applies to the individual patient as well as the health practitioner. Health care delivery is neither a quick fix, nor a "one remedy fits all" service.

\section{Conclusion}

Many titles been bestowed on Aristotle - a philosopher focusing on principles; a promoter of empiricism in medical practice; the first natural historian; and an educator. It is just as astounding to see how far Aristotle moved medical practice from its supernatural foundations in the direction of modern observational medicine, as it is to realize how far he moved philosophy from a speculative to an applied discipline. Medical practice is following empirical approaches that Aristotle championed, and is incorporating his broader philosophy into a possible new era of personalized medical practice. Aristotle would have agreed that the shape of this future medicine is outweighed by the tangible benefits it can produce in people's health.

\section{Stephen M. Modell}

Health Management and Policy University of Michigan School of Public Health 4605 SPH Tower 
109 S. Observatory

Ann Arbor, MI 48109-2029

U.S.A.

Email: $\underline{\bmod @ u m i c h . e d u}$

1. Albert S. Lyons and R. Joseph Petrucelli, Medicine: An Illustrated History (New York: Harry N. Abrams, Inc., Publishers, 1978), 176. Cited hereafter as MI.

2. Heikki S. Vuorinen, “But Hasn't Hippocrates Said it All Already? Philosophy of Medicine and Changing Traditions," in Philosophy for Medicine: Applications in a Clinical Context, ed. Martyn Evans, Pekka Louhiala, and Raimo Puustinen (Oxford, UK: Radcliffe Medical Press, 2004), 113-133.

3. Marshall Clagett, Greek Science in Antiquity (New York: Abelard-Schuman, Inc., 1955), 39. Cited hereafter as $G S$.

4. Bertrand Russell, A History of Western Philosophy (New York: Simon and Schuster, 1945), 160-1. Cited hereafter as $H W$.

5. James Longrigg, Greek Rational Medicine: Philosophy and Medicine from Alcmaeon to the Alexandrians (London: Routledge, 1993), 149. Cited hereafter as GR.

6. Aristotle, "On the Heavens" ("De Caelo") in The Complete Works of Aristotle, Vol. 1, ed. Jonathan Barnes (Princeton, NJ: Princeton University Press, Bollingen Series LXXI-2, 1984), 500. Cited hereafter as $C W$.

7. James G. Lennox, Aristotle's Philosophy of Biology: Studies in the Origin of Life Science (New York: Cambridge University Press, 2001), 35. Cited hereafter as AP.

8. Renford Bambrough, The Philosophy of Aristotle, ed. J. L. Creed and A. E. Wardman (New York: New American Library, 1963), 209-224.

9. Walter Pagel, New Light on William Harvey (London: S. Karger, 1976), 4. Cited hereafter as NL.

10. Alfred North Whitehead, Process and Reality (New York: Harper \& Row, 1957), 32.

11. Carl Friedrich von Weizsäcker, The Unity of Nature (New York: Farrar, Straus and Giroux), 263. 
12. Alfred I. Tauber, Confessions of a Medicine Man: An Essay in Popular Philosophy (Cambridge, MA: The MIT Press, 2000), 40.

13. Konstantin S. Khroutski, "Personalist Cosmology as the Ultimate Ground for a Science of Individual Wellness," Ultimate Reality and Meaning 29 (2006): 122-146.

14. Aristotle, "Nicomachean Ethics," in The Ethics of Aristotle, trans. J. A. K. Thomson (London: Unwin Brothers Limited, 1953), 26. 